\title{
Information Technology and Internal Auditors' Actvities in Nigeria
}

\author{
${ }^{1}$ Appah Ebimobowei and ${ }^{2}$ Emeh Yadirichukwu \\ ${ }^{1}$ Department of Accounting, Faculty of Business Education, \\ Bayelsa State College of Education, Okpoama, Brass Island, P.M.B. 74 Yenagoa, Nigeria \\ ${ }^{2}$ Department of Accountancy, Federal Polytechnic, Nekede, Imo State, Nigeria
}

\begin{abstract}
The study examines the effect of information technology on the activities of internal auditors in Nigeria. The study specifically investigates the relationship between information technology audit objectives and information technology evaluation control. To achieve this objective, data was collected from primary and secondary sources. The primary source was purely a well structured research questionnaire of three sections that was administered to the respective organizations sampled for the purpose of this research. A total of one hundred and fifty three questionnaires were returned and used for the analysis. The analysis was done with excel and eview software using ordinary least square multiple regression model. The results reveal that internal auditors in Nigeria are more concerned with the traditional functions of application control and system security, the evaluation of efficiency, effective and economy of information technology on IT evaluation controls and the evaluation of fairness of financial statement representation and the accuracy and completeness of computerized accounting system. On the basis of these, the researchers concluded that information technology should be seen by internal auditors in the 21 st century organizations as a competitive advantage in terms of cost savings, operational efficiency and reduction of human errors. Therefore, useful suggestions were put forward to ensure that internal audit functions in organizations are effectively and efficiently achieved to minimize financial, operational and environmental risks.
\end{abstract}

Key words: Internal audit, information technology, efficiency, human error, Nigeria

\section{INTRODUCTION}

The information and communication technology in the 21 st century have revolutionized the audit profession. Agbatogun et al. (2011) says that technology has been a significant tool in almost all human endeavours. Jaiyeola (2007) argues that ICT is like an engine that could be used in so many ways; the same engine that makes the aircraft to move could make a conveyor to convey finished product from production line to the storage location; the same could be used for automobile and grinding machine, etc. It is an implement in the hands of the accountant but enhances and improves its performance. Adedoyin (2010) argues that information technology have affected every profession in the last 20 years. The accounting profession is not left out in these profound changes to business and methods of communications. Technology is providing the tools that are revolutionalizing the role of financial professionals from that of information recorders to business strategists making them much more critical to the success of an enterprise (Jaiyeola, 2007). According to Uzoka (2002), information technology is the harnessing of electronic technology in its various forms to improve the operations and profitability of the business as a whole. It provides significant improvements with facilities such as word processing, communication facilities in the form of electronic mail, databases in relation to filling and data retrieval. Such advances improve business efficiency, eliminating unnecessary delays in communication between routine filling and correspondence. Also Ofurum and Ogbonna (2008) says information technology is the combination of computing, telecommunication and video techniques for the purpose of acquiring, processing, storing and disseminating vocal, pictoral, textual and numerical information. The computing techniques provide the capacity for processing and storing of information; the telecommunicating techniques provide the capacity for communicating the information to users and the video techniques, the capability for high quality display of images.

Many organizations are becoming increasingly dependent on information technology with such elements as fully integrated information systems and electronic document management becoming more popular.

Corresponding Author: Appah Ebimobowei, Department of Accounting, Faculty of Business Education, Bayelsa State College of Education, Okpoama, Brass Island, P.M.B. 74 Yenagoa, Nigeria 
According to Abu-Musa (n.d), information technology increases the accuracy and speed of transactions processing and can even lead to competitive advantages for many organizations in terms of operational efficiency, cost savings and reduction of human errors. Thus, information technology is associated with different types of risks such as loss of computer assets, erroneous record keeping, increased risk of fraud and competitive disadvantages if the wrong information technology is selected, loss or theft of data, privacy violations and business disruption (Hermanson et al., 2000; Hadden et al., 2003; Abu-Musa, 2006). According to Cannon and Crowe (2004), many internal controls over financial data are incorporated in computer programs, processes and procedures that are written, implemented and maintained by information technology function.

Abu-Musa (2006) argued that internal auditors are struggling to maintain their identity and purpose as the organizations they audit undergo radical changes. Total quality management, business process reengineering, globalization and self-directed teams are dismantling hierarchical command and control structures. Tongren (1997) argues that as advances in information technology continuously render control procedures obsolete and the value of traditional internal audit functions becomes serious questions. However, the International Standard on Auditing (ISA, 2006) 401-Auditing in Computer Information Systems Environment noted that auditing processes for both internal and external auditors have rapidly changed. These changes are prompted by globalization of business, advances in technology, demand for value-added audits, organizational structure of the client's computerized information systems activities, the extent of concentration or distribution of computer processing throughout the organization, particularly as they may affect segregation of duties and the availability of data source documents. Some computer files and other evidential matter that may be required by the auditor may exist for only a short period or only in machine-readable form. Therefore, the auditor should have sufficient knowledge and specialized skills of information communication and technology to plan, direct, supervise and review work performed. Fadzil et al. (2005) argues that internal auditing has undergone dramatic changes that have expanded its scope in a way that allows it to make greater contributions to the organization it serves. The internal auditor also walks a tight rope between serving as a management consultant and an independent professional. It is on the basis of this debate that the researcher examined the effect of Information Technology (IT) on internal audit activities in Nigeria.
Theoretical and empirical literature: Information technology is the combination of computing, telecommunication and video techniques for the purpose of acquiring, processing, storing and disseminating vocal, pictoral, textual and numerical information. Uzoka (2002) defined information technology as the harnessing of electronic technology in its various forms to improve the operations and profitability of the business as a whole. According to the International Federation of Accountants (IFAC), information technology would provide potential benefits for an organization's internal control system because it enables the organization to: Consistently apply predefined business rules and perform complex calculations in processing large volumes of transactions and data; enhances the timeliness, availability and accuracy of information; facilitates the additional analysis of information; enhances the ability to monitor the performance of the organizations activities and its policies and procedures; reduces the risk that controls will be circumvented; enhances the ability to achieve effective segregation of duties by implementing security controls in applications, databases and operating systems.

Internal auditing is an independent appraisal function within an organization for the review of the system of internal control and quality of performance as a service to the organization. It objectively examines, evaluates and reports on the adequacy of internal controls as a contribution to the proper, economic, efficient and effective use of resources (Okezie, 2008; Adeniji, 2004). The main objective of internal auditing is to assist management in the effective discharge of their responsibilities by furnishing them with analysis, appraisal, recommendations and pertinent comments concerning the activities reviewed. The International Standard on Auditing 610 considering the work of internal audit stated that the internal auditing activities include one or more of the following: Monitoring and control, examination of financial and operating information, review of the economy, efficiency and effectiveness of operations and review of compliance with laws, regulations and other external requirements and with management policies and directives and other internal requirements.

Silltow (2003) argues that internal auditors receive considerably more exposure to information technology nowadays than in the past. Information technology plays a significant role in the way modern organizations function and it becomes integrated to the degree that virtually every type of audit requires at least some consideration of information technology. Pathak (2003) pointed out that the overall quality of various systems of internal controls facilitates to a great extent the internal 
auditing of business systems applications in general. The researchers further suggested that an integration of applications and enterprise-wide information systems will be a key trend for the future and will surely have a great impact on the entire set of knowledge, skills, methods, algorithms and strategies of internal auditors. Abu-Musa (2008) argues that the use of information technology affects the manner in which transactions are initiated, recorded, processed and reported. An organization may have information systems that use automated procedures to initiate, record, process and report transactions in which case records in electronic format replace such study documents as purchase orders, invoices, shipping documents and related accounting records. Controls in systems that use information technology, consist of a combination of automated controls and manual controls. Furthermore, manual controls may be independent of information technology, may use information produced by information technology or may be limited to monitoring the effective functioning of information technology and of automated controls and to handling exceptions. Accordingly, the auditor should design and perform further audit procedures whose nature, timing and extent are responsive to the risk assessments.

According to Vatanasakdakul and Cooper, the advent of new technology has caused changes in audit approaches and in some cases it may cause change in the audit objectives. The information technology that relates to audit includes evaluation of efficiency/effectiveness/ economy of IT use; evaluation of compliance with policies, procedures and regulations; evaluation of internal control in computer-based system; evaluation of fairness of financial statement representations and the accuracy and completeness of computerized accounting records. Mahzan and Veerankutty (2011) listed auditors competence, type of auditor, new computer system, structure of computerized system and size of organizations as other objectives of information technology audit.

Hermanson et al. (2000) conducted a study to examine the information technology related activities of internal auditors in the United States of America. Information gathered from over one hundred directors of internal audit suggested that internal auditors focus basically on traditional information technology risks and control such as IT asset safeguarding, application processing and data integrity, privacy and security. Their results also revealed that several factors have been associated with internal auditors' performance of information technology evaluations.
Hadden et al. (2003) investigated the perceived information technology qualifications and IT activities of audit committees, internal auditors and external auditors regarding IT. The results showed that some organizations were able to achieve more effective information technology oversight by tapping into the resources of the audit committee and external auditor's to greater extent. The results revealed that internal auditors' commitment to IT oversight was rated above moderate.

Hunton examined the extent to which financial auditors and information systems audit specialists recognize differences in the nature and unique business and audit risks associated with ERP systems as compared with traditional computerized (non-ERP) system. The results showed that financial auditors are significantly less concerned of ERP risks compared with information system audit specialists.

Godwin-Stewart and Kent (2006) conducted the voluntary use of internal audit by Australian publicly quoted companies to identify the main factors leading quoted companies to have internal audit function. The result suggests that a large proportion of Australian listed companies do not use internal audit and many of those organizations that do have only one or two internal audit staff. The results also revealed an association between the use of internal audit and a commitment to strong risk management. A strong association between internal audit and the size of the organization has been found, suggesting that smaller organizations do not regard internal audit as cost effective.

Mahzan and Veerankutty (2011) examined information technology auditing activities of public sector auditors in Malaysia. The results show that application processing control and data integrity, privacy and security control were the most frequent evaluations performed by public sector auditors. The most frequent information technology audit objective is the evaluation of compliance with policies, procedures and evaluation of internal control and these objectives are performed differently in different divisions.

\section{MATERIALS AND METHODS}

The primary data for the study were generated through the administration of questionnaire conducted to evaluate the effect of information technology on internal auditors' activities in Nigeria on three hundred respondents (internal auditors) on manufacturing companies, financial institutions, government ministries, department and agencies, oil and gas companies, hotels, construction companies in five cities in Nigeria namely Asaba, Owerri, Port Harcourt, Warri and Yenagoa for the 
year 2011. The study used instruments developed by Hermanson et al. (2000) modified by Abu-Musa (2008) and Mahzan and Veerankutty (2011) in their respective studies based on the statement of Information Technology in the Accounting Curriculum of IFAC.

The first part of the questionnaire contains questions on organizations' and respondents' characteristics. The second part of questionnaire examined the audit evaluations of computer information system using 5 point scale of 1-rarely done, 2-occasionally done, 3 - frequently done, 4-often done and 5-always done for each objective. The third part of the questionnaire examined the specific tests of computerized information system outlined by IFAC using 5 point scale rated from 1 -rarely done, 2-occassionally done, 3-frequently done, 4-often done and 5-always done. The fourth part of the questionnaire examined the use of CAATs by internal auditors in Nigeria. A total of one hundred and fifty three usable questionnaires were completed and used for the analysis. The questionnaire were pre-tested using selected number of academic staff at the Department of Accounting, Bayelsa State College of Education, Okpoama, Brass-Island and Federal Polytechnic Nekede, Imo State, some practitioners and piloted on selected organizations in Yenagoa and Owerri. A reliability test was done on the collected data using Cronbach Alpha model, to explore the internal consistency of the questionnaire. The result of the reliability test shows that the questionnaire design is highly reliable at 0.865 . Excel software helped us to transform the variables into format suitable for analysis, after which the econometric view (Eview) was utilized for data analysis. The ordinary least square was adopted for the purpose of hypothesis testing. The ordinary least square was guided by the following linear model:

$$
\begin{array}{r}
\mathrm{Y}_{\mathrm{i}}=\alpha+\beta_{1} \mathrm{X}_{1}+\beta_{2} \mathrm{X}_{2}+\beta_{3} \mathrm{X}_{3}+\beta_{4} \mathrm{X}_{4}+\beta_{5} \mathrm{X}_{5}+ \\
\beta_{6} \mathrm{X}_{6}+\beta_{7} \mathrm{X}_{7}+\beta_{8} \mathrm{X}_{8}+\beta_{9} \mathrm{X}_{9}+\beta_{10} \mathrm{X}_{10}+\varepsilon
\end{array}
$$

Where:

$$
\begin{aligned}
\mathrm{Y}_{1}= & \text { Information technology evaluation } \\
\mathrm{Y}_{1}= & \text { System development and acquisition control } \\
\mathrm{Y}_{2}= & \text { System implementation control } \\
\mathrm{Y}_{3}= & \text { System maintenance and program changes } \\
& \text { control } \\
\mathrm{Y}_{4}= & \text { Information technology asset safeguarding } \\
& \text { control } \\
\mathrm{Y}_{5}= & \text { Data integrity, privacy and security control } \\
\mathrm{Y}_{6}= & \text { Continuing of processing and data recovery } \\
& \text { plan control } \\
\mathrm{Y}_{7}= & \text { Operating system and network control }
\end{aligned}
$$

$$
\begin{aligned}
& \mathrm{Y}_{8}=\text { Application processing control } \\
& \alpha=\text { Intercept of the regression } \\
& \beta_{1}-\beta_{9}=\text { The coefficient of the regression } \\
& \varepsilon=\text { The error term capturing other independent } \\
& \text { variables not explicitly included in the model } \\
& \mathrm{X}_{1}=\text { Evaluation of efficiency, effectiveness, } \\
& \text { economy of information technology usage } \\
& \mathrm{X}_{2}=\text { Evaluation of compliance with policies, statues } \\
& \text { and regulations } \\
& \mathrm{X}_{3}=\text { Evaluation of internal control in computer } \\
& \text { information system } \\
& \mathrm{X}_{4}=\text { Completeness of computer accounting records } \\
& \mathrm{X}_{5}=\text { The type of organization } \\
& \mathrm{X}_{6}=\text { The number of internal auditors } \\
& \mathrm{X}_{7}=\text { Percentage of computer auditors on the internal } \\
& \text { audit staff } \\
& \mathrm{X}_{8}=\text { Organization's computer information system } \\
& \mathrm{X}_{9}=\text { Percentage of new computer systems in the } \\
& \text { organization } \\
& \mathrm{X}_{10}=\text { The use of CAATs }
\end{aligned}
$$

The model was tested using the diagnostic tests of ascertain the assumptions of classical linear regression model of normality, linearity, heteroskedasticty, multicollinearity and autocorrelation. The results show no violation of the assumptions.

\section{RESULTS AND DISCUSSION}

This study discusses the multiple regression analysis of the effects of information technology on internal auditors' activities in Nigeria. The result obtained from the analysis to test the main hypothesis of the study which is stated in the null form as follows; HO: There is no significant relationship between information technology evaluations performed by internal auditors and audit objectives in Nigeria.

The results of the regression results are shown in the appendix. Data given in appendix show that evaluation of efficiency, effectiveness, economy and information technology usage (X1) is significantly related to system development and control (Y1) that is the p-value of 0.0089 is less than the critical value of 0.05 . However, all other explanatory variables are not significantly associated with the explained variable that is the $\mathrm{p}$-value is greater than the critical value of 0.05 . The $\mathrm{R}^{2}$ of about $14 \%$ show that the variations in system development control are explained by the explanatory variables with F-stat and prob stat of 2.423319 and 0.010710 . This result is consistent with the study conducted by Abu-Musa (2008) 
that internal auditors involvement in computer information system development and acquisition process and the number of internal auditors and the percentage of computer auditors. This result could be as a result of the availability of funds, lack of technical strength and skill of internal auditors and the relative simple size of most internal audit units (Mahzan and Veerankutty, 2011). Data given in appendix show that evaluation of efficiency, effectiveness, economy and information technology usage $\left(\mathrm{X}_{1}\right)$ and the number of internal auditors $\left(\mathrm{X}_{6}\right)$ are significantly related with system implementation control $\left(\mathrm{Y}_{2}\right)$ that is $\mathrm{p}$-value is less than the critical value $\{0.05>(0.0052,0.0132)\}$.

However, all other explanatory variables are not significantly related with the explained variables because the p-values are greater than the critical value of 0.05 . The $\mathrm{R}^{2}$ of about $17 \%$ variations in system implementation are explained by the explanatory variables with $\mathrm{F}$-stat and pro stat of 3.055245 and 0.001538 . This result conforms with the study of Abu Musa (2008) and Hermanson et al. (2000) a relationship exist between number of auditors and information technology assets safeguarding. Results given in appendix show that evaluation of internal control in computer information system $\left(\mathrm{X}_{3}\right)$, the number of internal auditors $\left(\mathrm{X}_{6}\right)$ and organizations computer information system is significantly related to system maintenance and program changes control that is the p-value is less than the critical value $\{0.05>0.0404,0.0257$ and 0.0003 ). However, all other explanatory variables are not significantly associated with organizations computer information system because p-value is greater than the critical value of 0.05 . The $\mathrm{R}^{2}$ about $23 \%$ variations in organizations computer information system are explained by the explanatory variables with $\mathrm{F}$-stat and pro-stat of 4.366973 and 0.000024 . This is in line with the study of Mahzan and Veerankutty (2011). Results given in appendix show that evaluation of efficiency, effectiveness and economy of information technology usage $\left(\mathrm{X}_{1}\right)$ is significantly related with information technology asset safeguarding control $\left(\mathrm{Y}_{4}\right)$ that is the p-value is less than the critical value $(0.05>0.0071)$. However, all other explanatory variables are not significantly related with the explained variable because the p-value is greater than the critical value of 0.05 . The $R^{2}$ of about $13 \%$ variations in information technology assets safeguarding are explained by the explanatory variables with F-stat and pro-stat of 2.160383 and 0.023546 . Results given in appendix show that evaluation of efficiency, effectiveness and economy of information technology usage $\left(\mathrm{X}_{1}\right)$ is significantly related to the type of organization $\left(\mathrm{Y}_{5}\right)$ that is the $\mathrm{p}$-value is less than the critical value $(0.05>0.0068)$. However, all other explanatory variables are not significantly related as a result of higher p-value. The $\mathrm{R}^{2}$ of about $13 \%$ shows that variation in type of organization is explained by the explanatory variables with F-stat and pro-stat of 2.164216 and 0.023284 . Results given in appendix show that evaluation of efficiency, effectiveness and economy of information usage $\left(\mathrm{X}_{1}\right)$ and percentage of computer auditors on the internal audit staff $\left(\mathrm{X}_{7}\right)$ are significantly related to continuing of processing and data recovery plan control. However, $\mathrm{R}^{2}$ of about $14 \%$ shows that variations in continuing of processing and data recovery plan control is explained by the explanatory variables with F-stat and pro stat of 0.014186 . Results given in appendix show that evaluation of efficiency, effectiveness and economy of information technology usage $\left(\mathrm{X}_{1}\right)$ is significantly related to operating system and network control $\left(\mathrm{Y}_{7}\right)$ that is the p-value is less than the critical value $(0.05>0.0158)$. However, $\mathrm{R}^{2}$ of about $11 \%$ shows that variation in operating system and network control is explained by the explanatory variables with $\mathrm{F}$-stat and pro stat of 1.921616 and 0.0046781 . Results given in appendix shows that evaluation of efficiency, effectiveness and economy of information usage $\left(\mathrm{X}_{1}\right)$ and percentage of computer auditors on the internal audit staff $\left(\mathrm{X}_{7}\right)$ are significantly related with application processing $\left(\mathrm{Y}_{8}\right)$. However, $\mathrm{R}^{2}$ of about $12 \%$ shows that variation in application processing is explained by the explanatory variables with F-stat and pro stat of 1.999176 and 0.037538 .

The results prevented above have shown that information technology is very fundamental to the effectiveness and efficient functioning of the internal auditors in the 21 st century complex organizations. However, this cannot be achieved as a result of the lack of funds mostly in government ministries, departments and agencies to acquire the much needed technical strength and sophistication of modern internal audit departments in Nigeria.

\section{CONCLUSION}

The study investigated the role of information technology on the activities of internal auditors in Nigeria. The study revealed that most of the organizations examined performed in the various areas of evaluations such as system development and acquisition controls, system maintenance and program changes and information technology asset safeguarding. The analysis provides evidence on the relationship between internal 
auditor's information technology evaluations with audit objectives and the features of organizations. The results revealed that internal auditors in Nigeria are more concerned with the traditional functions of application and systems control security. This may be as a result of the availability of experts in IT because most internals are trained as general auditors. The interesting result of the study shows that evaluation of the efficiency, effectiveness and economy on information technology usage appears to have the highest relationship with the areas identified by the International Federation of Accountants (IFAC). Therefore, information technology should be seen by internal auditors as a system that must be embraced totally in the 21 st century organizations to achieve competitive advantage in terms cost savings, operational efficiency and reduction of human errors.

\section{RECOMMENDATIONS}

On the basis of the conclusion, the following recommendations are provided:

- Internal auditors in Nigeria should enhance their knowledge and skills of information and communication technology to enable them plan, direct, supervise and review accounting work performed in a computer environment

- Government in Nigeria should ensure that internal audit units in the various Ministries, Departments and Agencies (MDAs) are properly equipped with state of the art IT facilities to enable accountants and auditors work in computerized environment

- A more specialized institute like that of the Institute of Chartered Accountants of Nigeria (ICAN) should be established to specifically deal with internal and management audit in Nigeria

- Management and managers of organizations should see internal audit as a necessary structure responsible for the smooth running of their respective organizations to prevent fraud and irregularities. Therefore, the internal audit units should be given adequate support for function properly

- Management of organizations should ensure that independent auditors perform more IT control evaluations

\section{ACKNOWLEDGEMENTS}

The researchers acknowledge the comments from $\mathrm{Mr}$. J.F. Isowo (FCCA, FCA) Principal Partner Freeman Isowo and Co. Chartered Accountants; Mr. Joseph Inini (Chief
Internal Auditor) BYCOE Okpoama Brass island and all the academic staff that provided the initial comments for the pilot study.

\section{APPENDIX}

(a): Dependent variable: Y1, Method: Least squares, Date: 07/07/11 Time: 19:24, Sample: 1 153, Included observations: 153

\begin{tabular}{lccrc}
\hline Variables & Coefficient & \multicolumn{1}{c}{$\mathrm{SE}$} & \multicolumn{1}{c}{ t-statistic } & Prob. \\
\hline $\mathrm{C}$ & 2.495424 & 0.700013 & 3.564828 & 0.0005 \\
$\mathrm{X}_{1}$ & -0.218768 & 0.082439 & -2.653711 & 0.0089 \\
$\mathrm{X}_{2}$ & -0.018650 & 0.073153 & -0.254946 & 0.7991 \\
$\mathrm{X}_{3}$ & 0.074676 & 0.080977 & 0.922192 & 0.3580 \\
$\mathrm{X}_{4}$ & -0.013149 & 0.075230 & -0.174787 & 0.8615 \\
$\mathrm{X}_{5}$ & -0.044173 & 0.081381 & -0.542790 & 0.5881 \\
$\mathrm{X}_{6}$ & -0.000873 & 0.066174 & -0.013199 & 0.9895 \\
$\mathrm{X}_{7}$ & 0.277931 & 0.158663 & 1.751698 & 0.0820 \\
$\mathrm{X}_{8}$ & 0.136193 & 0.091185 & 1.493583 & 0.1375 \\
$\mathrm{X}_{9}$ & 0.144397 & 0.075848 & 1.903785 & 0.0590 \\
$\mathrm{X}_{10}$ & -0.017643 & 0.050188 & -0.351536 & 0.7257 \\
\hline
\end{tabular}

$\mathrm{R}^{2}=0.145789$; Mean dependent var. $=2.856209 ;$ Adjusted $\mathrm{R}^{2}=0.085633$; $\mathrm{SD}$ dependent var $=0.969389 ; \mathrm{SE}$ of regression $=0.926954$; Akaike info criterion $=2.755355$; Sum squared resid $=122.0127$; Schwarz criterion $=$ 2.973229; Log likelihood $=-199.7846 ;$ F-statistic $=2.423519$; DurbinWatson stat $=2.171701 ;$ Prob $(\mathrm{F}$-statistic $)=0.010770$; eview program

(b): Dependent variable: $\mathrm{Y}_{2}$, Method: Least squares, Date: 07/07/11, Time: 19:26, Sample: 1153, Included observations: 153

\begin{tabular}{lcccc}
\hline Variables & Coefficient & SE & t-statistic & Prob. \\
\hline $\mathrm{C}$ & 1.982242 & 0.773852 & 2.561526 & 0.0115 \\
$\mathrm{X}_{1}$ & -0.236867 & 0.083195 & -2.847138 & 0.0051 \\
$\mathrm{X}_{2}$ & -0.093175 & 0.071509 & -1.302990 & 0.1947 \\
$\mathrm{X}_{3}$ & 0.149811 & 0.088324 & 1.696150 & 0.0920 \\
$\mathrm{X}_{4}$ & 0.003183 & 0.082660 & 0.038512 & 0.9693 \\
$\mathrm{X}_{5}$ & 0.002856 & 0.088922 & 0.032113 & 0.9744 \\
$\mathrm{X}_{6}$ & 0.172572 & 0.068770 & 2.509410 & 0.0132 \\
$\mathrm{X}_{7}$ & 0.259029 & 0.169197 & 1.530926 & 0.1280 \\
$\mathrm{X}_{8}$ & 0.095637 & 0.101609 & 0.941226 & 0.3482 \\
$\mathrm{X}_{9}$ & 0.128640 & 0.079128 & 1.625729 & 0.1062 \\
$\mathrm{X}_{10}$ & 0.062652 & 0.077404 & 0.809411 & 0.4196 \\
\hline $\mathrm{R}^{2}=0.177062$.
\end{tabular}

$\mathrm{R}^{2}=0.177062$; Mean dependent var. $=3.000000 ;$ Adjusted $\mathrm{R}^{2}=$ 0.119108 ; SD dependent var. $=1.038724$; $\mathrm{SE}$ of regression $=0.974903$; Akaike info criterion $=2.856222$; Sum squared resid $=134.9619$; Schwarz criterion $=3.074097$; Log likelihood $=-207.5010 ;$ F-statistic $=3.055245$; Durbin-Watson stat $=1.908143$; Prob $($ F-statistic $)=0.001538$; eview program

(c): Dependent variable: $\mathrm{Y}_{3}$, Method: Least squares, Date: 07/07/11, Time: 19:31, Sample: 1153 , Included observations: 153

\begin{tabular}{lccrc}
\hline Variables & Coefficient & \multicolumn{1}{c}{ SE } & t-statistic & Prob. \\
\hline $\mathrm{C}$ & 1.209254 & 0.686341 & 1.761886 & 0.0802 \\
$\mathrm{X}_{1}$ & -0.135869 & 0.082147 & -1.653965 & 0.1003 \\
$\mathrm{X}_{2}$ & -0.129077 & 0.068848 & -1.874797 & 0.0629 \\
$\mathrm{X}_{3}$ & 0.163191 & 0.078887 & 2.068668 & 0.0404 \\
$\mathrm{X}_{4}$ & -0.008685 & 0.079385 & -0.109408 & 0.9130 \\
$\mathrm{X}_{5}$ & 0.014508 & 0.087517 & 0.165774 & 0.8686 \\
$\mathrm{X}_{6}$ & 0.156666 & 0.069491 & 2.254494 & 0.0257 \\
$\mathrm{X}_{7}$ & 0.320032 & 0.162646 & 1.967655 & 0.0511 \\
$\mathrm{X}_{8}$ & 0.279049 & 0.076056 & 3.668993 & 0.0003 \\
$\mathrm{X}_{9}$ & 0.105224 & 0.076268 & 1.379671 & 0.1699 \\
$\mathrm{X}_{10}$ & 0.077226 & 0.074786 & 1.032627 & 0.3035 \\
\hline
\end{tabular}

$\mathrm{R}^{2}=0.235201$; Mean dependent var. $=3.000000$; Adjusted $\mathrm{R}^{2}=0.181342$; $\mathrm{SD}$ dependent var. $=1.038724 ; \mathrm{SE}$ of regression $=0.939834$; Akaike info criterion $=2.782954$; Sum squared resid $=125.4270$; Schwarz criterion $=$ 3.000829; Log likelihood $=-201.8960 ;$ F-statistic $=4.366973$; DurbinWatson stat $=2.186379 ;$ Prob $(\mathrm{F}$-statistic $)=0.000024$; eview program 
Asian J. Inform. Technol., 10 (6): 201-208, 2011

(d): Dependent variable: $\mathrm{Y}_{4}$, Method: Least squares, Date: 07/07/11, Time: 19:33, Sample: 1153 , Included observations: 153

\begin{tabular}{lrcrc}
\hline Variables & Coefficient & $\mathrm{SE}$ & $\mathrm{t}$-statistic & Prob. \\
\hline $\mathrm{C}$ & 2.596957 & 0.689494 & 3.766466 & 0.0002 \\
$\mathrm{X}_{1}$ & -0.227388 & 0.083248 & -2.731446 & 0.0071 \\
$\mathrm{X}_{2}$ & -0.019231 & 0.073152 & -0.262888 & 0.7930 \\
$\mathrm{X}_{3}$ & 0.085087 & 0.080916 & 1.051545 & 0.2948 \\
$\mathrm{X}_{4}$ & -0.007355 & 0.075968 & -0.096815 & 0.9230 \\
$\mathrm{X}_{5}$ & -0.038355 & 0.080663 & -0.475490 & 0.6352 \\
$\mathrm{X}_{6}$ & 0.003044 & 0.066403 & 0.045836 & 0.9635 \\
$\mathrm{X}_{7}$ & 0.298753 & 0.159310 & 1.875291 & 0.0628 \\
$\mathrm{X}_{8}$ & 0.081744 & 0.084416 & 0.968349 & 0.3345 \\
$\mathrm{X}_{9}$ & 0.131441 & 0.077540 & 1.695154 & 0.0922 \\
$\mathrm{X}_{10}$ & -0.002421 & 0.049280 & -0.049129 & 0.9609 \\
$\mathrm{R}^{2}=0.132050 ;$ Mean dependent var. $=2.856209 ;$ Adjusted R $\mathrm{R}^{2}=0.070926 ;$ \\
$\mathrm{SD}$ dependent var =0.969389; SE of regression $=0.934379 ;$ Akaike info \\
criterion = 2.771311, Sum squared resid = 123.9751; Schwarz criterion $=$ \\
2.989185; Log likelihood = -201.0053; F-statistic = 2.160383; Durbin- \\
Watson stat = 2.188836; Prob (F-statistic)=0.023546; eview program
\end{tabular}

(e): Dependent variable: $Y_{5}$, Method: Least squares, Date: 07/07/11, Time: 19:20, Sample: 1153 , Included observations: 153

\begin{tabular}{lccrc}
\hline Variables & Coefficient & \multicolumn{1}{c}{$\mathrm{SE}$} & \multicolumn{1}{c}{ t-statistic } & Prob. \\
\hline $\mathrm{C}$ & 2.557195 & 0.684467 & 3.736036 & 0.0003 \\
$\mathrm{X}_{1}$ & -0.229324 & 0.083437 & -2.748467 & 0.0068 \\
$\mathrm{X}_{2}$ & -0.019431 & 0.073147 & -0.265647 & 0.7909 \\
$\mathrm{X}_{3}$ & 0.085294 & 0.080908 & 1.054220 & 0.2936 \\
$\mathrm{X}_{4}$ & -0.005913 & 0.075930 & -0.077877 & 0.9380 \\
$\mathrm{X}_{5}$ & -0.037549 & 0.080684 & -0.465387 & 0.6424 \\
$\mathrm{X}_{6}$ & 0.005071 & 0.066366 & 0.076412 & 0.9392 \\
$\mathrm{X}_{7}$ & 0.299857 & 0.159178 & 1.883790 & 0.0616 \\
$\mathrm{X}_{8}$ & 0.085916 & 0.083651 & 1.027077 & 0.3061 \\
$\mathrm{X}_{9}$ & 0.132088 & 0.077534 & 1.703618 & 0.0906 \\
$\mathrm{X}_{10}$ & 0.009794 & 0.051849 & 0.188895 & 0.8504 \\
\hline
\end{tabular}

$\mathrm{R}^{2}=0.132253$; Mean dependent var. $=2.856209$; Adjusted $\mathrm{R}^{2}=0.071144$; $\mathrm{SD}$ dependent var. $=0.969389 ; \mathrm{SE}$ of regression $=0.934269 ;$ Akaike info criterion $=2.771076$; Sum squared resid $=123.9460$; Schwarz criterion $=$ 2.988951; Log likelihood $=-200.9873$; F-statistic $=2.164216$; DurbinWatson stat $=2.192711$; Prob (F-statistic) $=0.023284$; eview program

(f): Dependent variable: $Y_{6}$, Method: Least squares, Date: 07/07/11, Time: 19:37, Sample: 1153, Included observations: 153

\begin{tabular}{lcccc}
\hline Variables & Coefficient & $\mathrm{SE}$ & \multicolumn{1}{c}{ t-statistic } & Prob. \\
\hline $\mathrm{C}$ & 3.026131 & 0.685715 & 4.413103 & 0.0000 \\
$\mathrm{X}_{1}$ & -0.180401 & 0.078503 & -2.298021 & 0.0230 \\
$\mathrm{X}_{2}$ & -0.048287 & 0.069089 & -0.698910 & 0.4858 \\
$\mathrm{X}_{3}$ & 0.010820 & 0.080386 & 0.134603 & 0.8931 \\
$\mathrm{X}_{4}$ & -0.024364 & 0.074237 & -0.328188 & 0.7433 \\
$\mathrm{X}_{5}$ & -0.083850 & 0.081754 & -1.025633 & 0.3068 \\
$\mathrm{X}_{6}$ & 0.024262 & 0.064436 & 0.376526 & 0.7071 \\
$\mathrm{X}_{7}$ & 0.415605 & 0.118920 & 3.494824 & 0.0006 \\
$\mathrm{X}_{8}$ & 0.051845 & 0.094706 & 0.547426 & 0.5849 \\
$\mathrm{X}_{9}$ & 0.060403 & 0.074566 & 0.810052 & 0.4193 \\
$\mathrm{X}_{10}$ & 0.024549 & 0.071015 & 0.345696 & 0.7301 \\
\hline
\end{tabular}

$\mathrm{R}^{2}=0.141044$; Mean dependent var. $=2.803922$; Adjusted $\mathrm{R}^{2}=0.080554$; SD dependent var. $=0.939336 ; \mathrm{SE}$ of regression $=0.900708$; Akaike info criterion $=2.697910$; Sum squared resid $=115.2012$; Schwarz criterion $=$ 2.915784; Log likelihood $=-195.3901 ;$ F-statistic $=2.331697$; DurbinWatson stat $=2.241366$; Prob $(\mathrm{F}$-statistic $)=0.014186$; eview program

(g): Dependent variable: $\mathrm{Y}_{7}$, Method: Least squares, Date: 07/07/11, Time: 19:40, Sample: 1153, Included observations: 153

\begin{tabular}{lcccc}
\hline Variables & Coefficient & SE & t-statistic & Prob. \\
\hline $\mathrm{C}$ & 3.623766 & 0.752370 & 4.816469 & 0.0000 \\
$\mathrm{X}_{1}$ & -0.194365 & 0.079583 & -2.442312 & 0.0158 \\
$\mathrm{X}_{2}$ & -0.056490 & 0.071556 & -0.789462 & 0.4312 \\
$\mathrm{X}_{3}$ & -0.018517 & 0.080577 & -0.229802 & 0.8186 \\
$\mathrm{X}_{4}$ & -0.043938 & 0.076031 & -0.577893 & 0.5643 \\
\hline
\end{tabular}

(g): Continue

\begin{tabular}{lcccc} 
Variables & Coefficient & $\mathrm{SE}$ & $\mathrm{t}$-statistic & Prob. \\
\hline $\mathrm{X}_{5}$ & -0.091907 & 0.081615 & -1.126099 & 0.2620 \\
$\mathrm{X}_{6}$ & 0.037656 & 0.063220 & 0.595643 & 0.5524 \\
$\mathrm{X}_{7}$ & 0.294998 & 0.153129 & 1.926463 & 0.0560 \\
$\mathrm{X}_{8}$ & 0.044252 & 0.092497 & 0.478420 & 0.6331 \\
$\mathrm{X}_{9}$ & 0.068662 & 0.072532 & 0.946638 & 0.3454 \\
$\mathrm{X}_{10}$ & -0.067903 & 0.058028 & -1.170190 & 0.2439 \\
$\mathrm{R}^{2}=0.119195 ;$ Mean dependent var. $=2.790850 ;$ Adjusted R & $=0.057166 ;$ \\
SD dependent var. $=0.922337 ;$ SE of regression $=0.895585 ;$ Akaike info \\
criterion = 2.686502; Sum squared resid = 113.8944; Schwarz criterion = \\
2.904376; Log likelihood = -194.5174; F-statistic = 1.921616; Durbin- \\
Watson stat = 2.232078; Prob (F-statistic) = 0.046781; eview program
\end{tabular}

(h): Dependent variable: $\mathrm{Y}_{8}$, Method: Least squares, Date: 07/07/11, Time: 19:45, Sample: 1153 , Included observations: 153

\begin{tabular}{lcccc}
\hline Variables & Coefficient & SE & t-statistic & Prob. \\
\hline $\mathrm{C}$ & 3.286417 & 0.802580 & 4.094816 & 0.0001 \\
$\mathrm{X}_{1}$ & -0.197176 & 0.079294 & -2.486659 & 0.0141 \\
$\mathrm{X}_{2}$ & -0.067756 & 0.070915 & -0.955449 & 0.3410 \\
$\mathrm{X}_{3}$ & -0.007308 & 0.080202 & -0.091120 & 0.9275 \\
$\mathrm{X}_{4}$ & -0.048446 & 0.076762 & -0.631122 & 0.5290 \\
$\mathrm{X}_{5}$ & -0.123220 & 0.086165 & -1.430052 & 0.1549 \\
$\mathrm{X}_{6}$ & 0.003340 & 0.066215 & 0.050442 & 0.9598 \\
$\mathrm{X}_{7}$ & 0.359489 & 0.153474 & 2.342341 & 0.0206 \\
$\mathrm{X}_{8}$ & 0.051100 & 0.093904 & 0.544175 & 0.5872 \\
$\mathrm{X}_{9}$ & 0.015886 & 0.076255 & 0.208324 & 0.8353 \\
$\mathrm{X}_{10}$ & 0.111833 & 0.064753 & 1.727070 & 0.0863 \\
$\mathrm{R}^{2}=0.123412 ;$ Mean dependent var. $=2.790850 ;$ Adjusted R $\mathrm{R}^{2}=0.061681 ;$ \\
$\mathrm{SD}$ dependent var. =0.922337; SE of regression $=0.893439 ;$ Akaike info \\
criterion = 2.681702; Sum squared resid = 113.3491; Schwarz criterion $=$ \\
2.899577; Log likelihood = -194.1502; F-statistic = 1.999176; Durbin- \\
Watson stat = 2.230633; Prob (F-statistic) =0.037538; eview program
\end{tabular}

\section{REFERENCES}

Abu-Musa, A. A., 2006. Evaluating the security controls of CAIS in Developing Countries: The case of Saudi Arabia. Int. J. Digital Accounting Res., 6: 25-64.

Abu-Musa, A. A., 2008. Information technology and its implications for internal auditing: An empirical study of Saudi organizations. Manage. Auditing J., $23: 438-466$.

Adedoyin, T., 2010. IT productivity tools for managing the accounting function. Niger. Accountant, 43: 30-36.

Adeniji, A.A., 2004. Auditing and Investigation. Value Analysis Consult Publishers, Lagos.

Agbatogun, A.O., P.A. Ajelabi, L.M. Oyewusi and J. Inegbedion, 2011. Computer-Assisted programmed instruction revisited: A study on teaching typewriting in nigeria higher institution Asian J. Inform. Technol., 10: 60-64.

Cannon, D.M. and G.A. Crowe, 2004. Soa compliance: Will it sabotage your efforts? J. Corporate Accounting Finance, 15: 31-37.

Fadzil, F.H., H. Haron and M. Jantan, 2005. Internal auditing practices and internal control system. Managerial Auditing J., 20: 844-866. 
Godwin-Stewart, J. and P. Kent, 2006. The use of internal audit by Australian companies. Managerial Audit J., 21: 81-101.

Hadden, L.B., F.T. Dezoort and D.R. Hermanson, 2003. IT risk oversight: The roles of audit committees, internal auditors and external auditors. Int. Auditing, 18: $28-30$.

Hermanson, D.R., M.C. Hill and D.M. Ivancevich, 2000. Reply to discussion of information technologyrelated activities of internal auditors. J. Inform. Syst., 14: 39-53.

ISA, 2006. Auditing. BPP Publishers, Lagos.

Jaiyeola, R., 2007. Information communication technology as a tool for effective performance of chartered accountants. Nig. Accountant, 40: 48-49.
Mahzan, N. and F. Veerankutty, 2011. IT auditing activities of public sector auditors in Malaysia. Afr. J. Bus. Manage., 5: 1551-1563.

Ofurum, C.O. and G.N. Ogbonna, 2008. Accounting Information Systems. Bon Publication, Owerri.

Okezie, B.N., 2008. Audit and Assurance Services. Concept Publishing, Mohan Garden, Delhi.

Pathak, J., 2003. It auditing and electronic funds transfer. Internal Auditing, 18: 28-28.

Silltow, J., 2003. Shedding light on information technology risks. Int. Auditors, 60: 32-38.

Tongren, J.D., 1997. Co-Active audit: The enhancement audit model. Managerial Finance, 23: 44-51.

Uzoka, F.M., 2002. Effects of information technology on customers satisfaction in nigerian financial institutions. Nig. Accountant, 35: 5-8. 